\title{
SOME BIOTIC AND ABIOTIC VARIABLES CONTROLLING PRIMARY PRODUCTIVITY IN HYPERTROPHIC LAKE, (LAKE QARUN-EGYPT)
}

\author{
Ahmed M. Abdel-Monem and Adel H. Kanswa \\ National Institute of Oceanography and Fisheries. \\ El-Kanater El-kheirea Research, Station
}

Key words: primary productivity, ${ }^{14} \mathrm{C}$, phytoplankton biomass. Lake Qarun.

\begin{abstract}

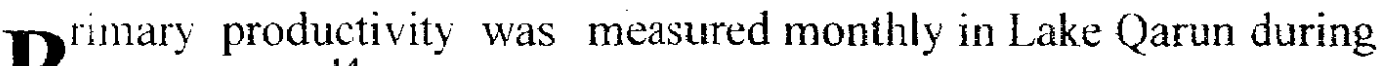
1993 using ${ }^{14} \mathrm{C}$ technique and the annual average value was 105.5 mg C m $\mathrm{Ch}^{-3}$. The study revealed that both biotic and abiotic variables have affected the primary productivity. Phytoplankton biomass, as biotic factor, was represented by total Chlorophyll $a$ (annual average of $26 \mathrm{mg} \mathrm{m}^{-3}$ ). Chlorophyll $a$ was fractionated into two major groups based on their availability to herbivorous zooplankton; nanoplankton $(<20 \mu)$ or edible algae and netplankton $(>20 \mu)$ or inedible algae. Nanoplankton was dominated and represented by about $69.4 \%$ of total phytoplankton, while netplankton was about $30.6 \%$. Size fraction ratio was controlled by their relative size-specific growth rates not by herbivorous zooplankton. There was a linear relationship between the relative contribution of nanoplankton and total algal biomass $(r=0.96$, $p>95$ ). Primary productivity has been affected by nanoplankton more than any other biotic variable.

Abiotic parameters (physical and chemical) were also studied and discussed in relation to its effect on primary productivity. The statistical analysis cleared that water temperature and $\mathrm{NO}_{3}-\mathrm{N}$ were the main factors regulating primary productivity among all ecological parameters tested.
\end{abstract}

\section{INTRODUCTION}

The importance of primary productivity measurements is well established and documented. There are miny ecological factors that 
control seasonality in primary productivity, mostly abiotic such as ligni climate, turbidity, rutrients, etc (Talling 1971; Jewson \& Wood, 1975; Tilzer, 1989). Nevertheless, primary productivity temporal controls by the food web has been recently shown to be sometimes as influential as the aforementioned abiotic factors (Carpenter et al.. 1987). Tilzer (1983) pointed out that the fraction of light absorbed by algae increases with biomass but decreases with raising inorganic turbidity. Water movement can result in marked variations in interception of light by phytoplankton (Grobbelaar \& Stegmann, 1976). Therefore, it is necessary to pay attention to other biotic components of the lacustrine ecosystem if a clear picture of the primary productivity is to be achicved. This is specially true for hypertrophic ecosystem. where physical features are suspected to control primary productivity in view of nutrient excess (Robarts, 1984). The relative importance of various nutrients in regulating algal productivity and biomass in lakes may change as a result of both anthropogenic and natural phenomena. These changes can happen daily (Schindler \& Free, 1973), seasonal (Lehman \& Sandgren 1978). and at longer time scales (Schindler 1977). In fact, nutrient pools in hypertrophic lakes are much enough not to be depleted by phytoplankton photosynthesis in the time domain this process occur, thus physical factors are of prime significance as controlling factors of primary productivity (Alvarez Cobelas et al., 1992).

Egyptian Lakes had a wide range of trophic status but their primary productivity have been poorly covered. The use of ${ }^{14} \mathrm{C}$ ieclinique increases the accuracy of its measurements. There fore, the aim of this study is to investigate the monthly variation of primary productivity in Lake Qarun as related to some biotic and abiotic factors, that may control and affect its variability.

\section{MATERIAL AND METHODS}

Study site:

Lake Qarun is situated in the Western Desert, about $83 \mathrm{~km}$ south Cairo and occupies the lowest part in El-Fayioum Depression. The Lake is used as a reservoir for agricultural drainage water. The drainage water discharges into the Lake via two main drains; El-Bats at the east and El-Wadi at the middle, in addition to some pumping stations at the southern side as shown in Figure (1). The Lake has an 
area of about $228 \mathrm{~km}^{2}$ (45 km length and $6 \mathrm{~km}$ mean width) with an average depth of about $4.2 \mathrm{~m}$ at $45 \mathrm{~m}$ below the sea level. Phytoplankton community inhabiting the Lake is represented by 5 classes. Bacillariophyceae is the major one (64\%) followed by Dinophyceac $(27 \%)$ while Chlorophyceae, (yanophyceae and Euglinophyceae are scarce. The climax standing crop is recorded in summer. Diatoms are dominated by Nizschia closterium, $N$. frustulum and Cyclotella glomerata. Dinoflagellates are dominated by Prorocentrum micans and Exovilla apora (Abdel Monem. 1991). Z.ooplankton is dominated by Brachiounus plicatilis in summer. while nauplius larvae (Copepoda) and Tintinnopsis strigosa (Protozoa) are the most abundant in winter and spring (Fl-Shabrawy \& Taha, 1999).

\section{Sampling and analyses:}

Monthly sampling program was conducted during 1993 The Lake was represented by 9 stations covering the different ecological habitats of the lake (Fig.1). Composite water samples were collected using Ruttner Bottle (2-liter capacity). Water depths were measured using Portable Echosounder (Lowrance x25). Water temperature and $\mathrm{pH}$ were measured in situ using Portable Electrochemistry Analyser (model $340 \mathrm{~S}$ ). A black and white standard Secchi-disc (25cm diameter) was used in measuring transparency. Nephelometric method (APHA, 1992) was applied for measuring water turbidity using digital and calibrated (Orbeco-Helling standard) direct-reading turbidity meter (mod. Orbeco-Helling). $\mathrm{HCO}_{3} \& \mathrm{CO}_{3}$ were determined titerametrically with standard $\mathrm{H}_{2} \mathrm{SO}_{4}$ using phenolphthalein and Methyl orange as indicators. Winkler method was used in detection of oxygen contents as discussed in APHA (1992).

Ammonium $\left(\mathrm{NH}_{4}-\mathrm{N}\right)$ was determined using the phenate method (Booth \& Lobring, 1973). Nitrite $\left(\mathrm{NO}_{2}-\mathrm{N}\right)$ was detected by diazotization method (Barnes \& Folkard, 1951). Cadmium reduction method (Nydahi, 1976) was applied in reducing and detection of Nitrate $\left(\mathrm{NO}_{3}-\mathrm{N}\right)$. Total inorganic nitrogen (TIN) was calculated as summation of the previous inorganic nitrogen contents. Orthophosphate $\left(\mathrm{PO}_{4}-\mathrm{P}\right)$ was measured colorimetery as discussed by Strickland \& Parsons (1972). 


\section{Primary Productivity:}

3. was measured by light and dark bottles using ${ }^{14} \mathrm{C}$ technique (Strickland \& Parsons, 1972). Two light and one dark glass bottles were filled with the Lake water and injected by about $1 \mu \mathrm{Ci}$ $\mathrm{NaH}^{i 4} \mathrm{CO}_{3}$. lncubation were carried out for $3-4 \mathrm{~h}$ on board (at the ambient day light between 10,00 and $14,00 \mathrm{~h}$ ) immediately after sampling. In the field laboratory, incubated water samples were filtered over $0.45 \mu \mathrm{m}$ Whatman cellulose acetate membrane filter under reduced pressure $(<10 \mathrm{~cm} \mathrm{Hg})$. Then the filters were placed in $\mathrm{HCl}$ fumes for $30 \mathrm{~min}$. (Evans et al., 1987). Kontrogel Scintillation cocktail were added and the samples were counted in the next day using Kontron Betamatic IV Liquid Scintillation Counter. The specific activity of the ${ }^{14} \mathrm{C}$ solution was checked immediately (Robarts, 1981). Production rates were calculated as discussed by Strickland \& Parsons (1972). The precautions in using ${ }^{14} \mathrm{C}$ technique in estimation of primary productivity in natural water (Peterson, 1980) were applied.

The biotic nature mainly included algal biomass as represented by Chlorophyll $a(\mathrm{Chl} a)$ with its deferent size fractions. Since zooplankton readily ingest particles up to approximately $35 \mu \mathrm{m}$ (Gliwicz, 1977), two major groups of phytoplankton based on their availability to herbivorous zooplankton were taken: nanoplankton $(<20 \mu)$ or edible algae and netplankton $(>20 \mu)$ or inedible algae as defined by Sieburth et al, (1978).

\section{Size fractionation of $\mathrm{Chl} a$ :}

Since zooplankton readily ingest particles up to approximately $35 \mu \mathrm{m}$ (Gliwicz, 1977), two major groups of phytoplankton based on their availability to herbivorous zooplankton were taken: nanoplankton or edible algae $(<20 \mu)$ and netplankton or inedible algea $(>20 \mu)$ as defined by Sieburth et,al.(1978).

Water samples were filtered through plankton net $20 \mu$ mesh size in order to separate netplankton and the filtered water contained nanoplankton. Chl $a$ for filtered (nanoplankton) and nonfiltered water (tcialplankton) were separated on a Watman glass microfiber filter (GF/F) using Sartorius filtration unit connected with plastic holder (13mm diameter). It was extracted in cold $90 \%$ acetone (Parsons et al., 1984) at $4{ }^{\circ} \mathrm{C}$ for $24 \mathrm{~h}$ and assaycd in Tumer 111 Fluorometer (Yentsch \& Menzal, 1963 and Holm-Hansen ef al.. 1965) calihrated with a standard solution of Chl a (Sigma Chemicals). Net (hl a was gained from subtracting nano from total $\mathrm{Chl} a$. 
Statistical analyses were carried out for the given parameters using BMDP new computer system, version 1.0. Correlation for total Chl $a$ with its fractions was calculated and simple linear regression with nano $\mathrm{Chl} a$ was done. Also, Correlation for primary productivity with physical, chemical and size fractions of $\mathrm{Chl} a$ was calculated. A multiple linear regression for primary productivity with the high correlated factors was tested.

\section{RESULTS}

\section{Depth and transparency:}

The highest water level of Lake Qarun was recorded in February $(4.56 \mathrm{~m})$ and decreased gradually to the lowest level in October $(3.73$ $\mathrm{m})$ with an annual average depth of $4.1 \mathrm{~m}$. Maximum water transparency, as represented by Secchi-depth readings, was recorded in October $(68 \mathrm{~cm})$ while the lowest value $(35 \mathrm{~cm})$ in May (Fig. 2).

\section{Water temperature:}

Water temperature was reached to its highest reading of $28.3{ }^{\circ} \mathrm{C}$ in June and gradually decreased to the lowest reading of $14.1^{\circ} \mathrm{C}$ in January as shown in Figure (3).

\section{pH:}

The monthly changing in $\mathrm{pH}$ values was irregular and lies in the alkaline side. Figure (4) shows that $\mathrm{pH}$ levels were fluctuated between the maximal value of 8.78 in April and the minimal of 7.93 in November.

\section{Turbidity:}

Water turbidity had a great monthly variation (Fig. 5) It ranged from 12.8 NTU in April to 46.2 NTU in September with an annual average value of 26.5 NTU.

\section{Dissolved oxygen:}

Dissolved oxygen in both surface and bottom layers had the same trend in its monthly variation with a slight decrease in the bottom (Fig.6). Their maximum concentrations of 11.01 and $8.82 \mathrm{mg}$ $\mathrm{O} \mathrm{I}^{-1}$ were found in January, while the minimum of 6.11 and $4.97 \mathrm{mg}$ $\mathrm{O} \mathrm{I}^{-1}$ were recorded in May with annual average values of 7.91 and 6.4 mg $\mathrm{Ol}^{-1}$ for both layers. respectively. 


\section{Alkalinity:}

Water alkalinity was dominated by $\mathrm{HCO}_{3}$ during the year as shown in Fig. (7). It reached to the highest level in October $\left(348 \mathrm{mg}^{1 /}\right.$ ) when the maximum values of $\mathrm{CO}_{3}$ and $\mathrm{HCO}_{3}$ were 103.6 and $244.4 \mathrm{mg} \mathrm{I}^{-1}$, respectively, while its lowest level was detected in May (101.3 $\mathrm{mg}^{-1}$ ) with a minimum values of 32.9 and 68.4 for both contents, respectively. Its annual average value was $210.1 \mathrm{mg} \mathrm{l}^{-1}$ (59 and $142.1 \mathrm{mg} \mathrm{l}^{-1}$, for $\mathrm{CO}_{3}$ and $\mathrm{HCO}_{3}$ respectively).

\section{Nutrients:}

TIN (total inorganic nitrogen): The lake water has a significant monthly fluctuation in its TIN along the investigated period as shown in Figure (8). Its concentration was ranged from the maximum of 480 $\mathrm{mg} \mathrm{m}^{-3}$ in June to the minimum of $71 \mathrm{mg} \mathrm{m}^{-3}$ in February with annual average of $200 \mathrm{mg} \mathrm{m}^{-3}$. The annual average of its composition showed that it is dominated by $\mathrm{NH}_{4}-\mathrm{N}(59.9 \%)$ followed by $\mathrm{NO}_{3}(36.4 \%)$, then $\mathrm{NO}_{2}(3.9 \%)$.

\section{$\mathrm{NH}_{4}-\mathbf{N}$ :}

The highest value of $\mathrm{NH}_{4}-\mathrm{N}$ amounted to $379 \mathrm{mg} \mathrm{m}^{-3}$ and recorded in June, while the lowest value $\left(17.7 \mathrm{mg} \mathrm{m}^{-3}\right)$ was in December.

$\mathrm{NO}_{3}-\mathbf{N}$ :

An obvious increase of $\mathrm{NO}_{3}-\mathrm{N}$ concentrations was observed during summer. Its highest value of $222.1 \mathrm{mg} \mathrm{m}^{-3}$ was found in July while the lowest value of $11.5 \mathrm{mg} \mathrm{m}^{-3}$ was recorded in February. $\mathrm{NO}_{2}-\mathrm{N}$ :

Its concentrations had an irregular monthly variations. It decreased from $15.1 \mathrm{in}$ June to $1.3 \mathrm{mg} \mathrm{m}^{-3}$ in August with an annual average value of $7.5 \mathrm{mg} \mathrm{m}^{-3}$.

$\mathrm{PO}_{4}-\mathrm{P}$ :

There was a great variation between its two extreme values (Fig. 9) which increased from 12.9 in February to $99.4 \mathrm{mg} \mathrm{m}^{-3}$ in A pril, with an annual average value of $54.6 \mathrm{mg} \mathrm{m}^{-3}$. 


\section{Total Chl a:}

Oscillation of total Chl a was more or less similar to such found in primary productivity. It varied from 41.5 in July to $8.0 \mathrm{mg} \mathrm{m}^{-3}$ in February with an annual average of $26 . \mathrm{mg} \mathrm{m}^{-3}$. Size fractionation of total $\mathrm{Chl} a$ has cleared the dominance of nanoplankton representing about $69.4 \%$ of total plankton, while netplankton composed only $30.6 \%$ from its contents. Nanoplankton raised from 5.2 $(65 \%)$ in January to $29.5 \mathrm{mg} \mathrm{m}^{-3}(77 \%)$ in August with annual average of $18 \mathrm{mg} \mathrm{m}^{-3}$ while netplankton oscillated between 2.9 (35\%) and 14.5 $m g \mathrm{~m}^{-3}(43 \%)$ in January and May respectively, with an annual average value of about $8 \mathrm{mg} \mathrm{m}^{-3}$ (Fig.10)

Statistical analysis indicated a high positive relationship between nanoplankton and total $\mathrm{Chl} a(\mathrm{r}=0.96, \mathrm{p}>95)$ with a linear regression. which can be represented by the following equation:

$$
y=0.7128 x-0.4918 \text { (where } y=\text { nano } C h l a \text { and } x=\text { total ( hl } a \text { ) }
$$

\section{Primary productivity:}

Lake Qarun primary productivity had a gradual decrease from the major peak of $217 \mathrm{mg} \mathrm{C} \mathrm{m} \mathrm{m}^{-3} \mathrm{~h}^{-1}$ in July to the minimum productivity of $26.6 \mathrm{mg} \mathrm{C} \mathrm{m}^{-3} \mathrm{~h}^{-1}$ in February. Its annual average value amounted to $105.5 \mathrm{mg} \mathrm{C} \mathrm{m}^{-3} \mathrm{~h}^{-1}$ (Fig.3).

Application of statistical analysis for correlation of primary productivity with biotic and abiotic variables showed that water temperature, $\mathrm{NO}_{3}-\mathrm{N}$ and nanoplankton had the highest significantly positive correlation's with productivity $(\mathrm{r}=0.93,0.81$ and 0.9 , respectively, $\mathrm{p}<0.05$ ) among all ecological parameters tested. A multiple linear regression was fitted for primary productivity with those factors $\left(R^{2}=0.83\right)$, resulting the following equation:

Primary productivity $=3.023 n+0.196 \mathrm{NO}_{3}+6.271 \mathrm{t}-98.38$ where: $\mathrm{n}=$ nano $\mathrm{Chl} a$ and $\mathrm{t}=$ water temperature.

Total Chl $a$ and netplankton were also positively correlated with primary productivity $(\mathrm{r}=0.88$ and 0.59 respectively $\mathrm{P}<0.05)$ but less than nanoplankton. Also, it has statistically significant relationship with TIN between weak $(r=0.61, p<0.05)$. No higher correlation existed with $\mathrm{NO}_{2}-\mathrm{N}$ and $\mathrm{NH}_{4}-\mathrm{N}(\mathrm{r}=0.42,0.31)$ as abiotic variable. No such significance could be also found for $\mathrm{pH}$, alkalinity $\left(\mathrm{CO}_{3}\right.$ and $\left.\mathrm{HCO}_{3}\right)$, transparency, dissolved oxygen and $\mathrm{PO}_{4}$. The environmental variables and statistically significant autocorrelation with primary 
productivity were illustrated in Table (I).

\section{DISCUSSION}

Lake Qarun lies in a subtropical arid area. Its climate has a high amplitude of water temperature $\left(14.2^{\circ} \mathrm{C}\right)$ fluctuated from hot summer to cold winter. The nature of the Lake as a reservoir for agricultural drainage water and waste waters characterized it with specific features. Physically, it is shallow, turbid and has a low transparency. Chemically, the Lake water is saturated with oxygen in the surface layer and slightly decreased in the bottom. It has high nitrogen content, in addition to some heavy metals and pesticides as reported by Anon (1997). $\mathrm{NH}_{4}-\mathrm{N}$ and $\mathrm{NO}_{3}-\mathrm{N}$ alternated the dominance through the year, while $\mathrm{NO}_{2}-\mathrm{N}$ was rare. $\mathrm{NO}_{3}-\mathrm{N}$ was the most limiting nitrogen factor on the activity of phytoplankton.

Phytoplankton biomass increased during the hot period and decreased in the cold. Its annual average was more or less similar to that recorded during 1989 (Abdel-Monem, 1991). Its size fraction reflected the dominance of nanoplankton $(69.4 \%)$ along the year. Oscillation of net and nanoplankton ratio can be attributed to either changes in their relative size-specific growth rates with increased nutrient supply and its response to enrichment or interactions among the various algal species and other biotic components of their environment. Also it may be regulated by herbivorous zooplankton. The experimental studies on grazing pressure in the Lake indicated the controlling of zooplankton on phytoplankton biomass during summer and it was mainly on nano \& picoplankton (El-Shabrawy \& Taha, 1999). In spite of the grazing pressure on nanoplankton, its percentage increases with elevation of total phytoplankton. This relationship can be referred to the oscillation in size fraction ratio due to the changes in their relative size-specific growth rates. The same close relation ship between total and nanoplankton was obtained by Waston \& McCauley (1988) in many lakes but contradicted with Kalff \& Watson (1986) in tropical lakes.

Concerning trophic state, primary productivity in Lake Qarun undergoes extreme monthly fluctuations. This certainly seems to be the case for productivity in hypertrophic lakes as suggested by Barica (1981). It is well known that the factors controlling primary productivity are mostly abiotic in nature (Tilzer, 1989). Also Harris et 
al (1980) stated that among the environmental abiotic factors, physical factors are supposedly to play the role in eutrophic and hypertrophic ecosystems. But Roberts (1984) has paid attention to other biotic components of the ecosystem on hypertrophic lakes. The present study in Lake Qarun suggested that primary productivity is controlled by both biotic and abiotic factors. This could result from the complex interactions among primary productivity and the ecological factors. Naturally, algal biomass is the most important biotic factor that effects the primary productivity. But that the controlling of nanoplankton on the Lake productivity $(\mathrm{r}=0.9)$ was higher than that found with netplankton $(r=0.59)$. This result agrees with that observed by Harris (1978) who stated that, in most eutrophic lakes, nanoplankton is the most important size fraction of phytoplankton, both in biomass and productivity.

Physically, primary productivity was highly water temperature dependent $(r=0.93)$. The same relation was found in the eutrophic part (Upper Lake) of Wadi El-Rayin Lakes (Taha and Abdel Monem, 1999) which lies in the same region. Not only water temperature plays a role in controlling primary productivity in the present lake, but also the chemical environment could be important too. The statistically significant correlation between primary productivity and $\mathrm{NO}_{3}-\mathrm{N}$ $(r=0.81)$ reflect the role of chemical status on oscillation of the lake productivity. The regular oscillation of primary productivity can arise slowly from the interactions of phytoplankton populations and their limiting nutrients as maintained by Jassby et al. (1992). On the other hand, multiple regression of the different environmental factors with primary productivity cleared that temperature is not being the only environmental feature that explains that variance in all months. Differences can be attributed to the ecological individuality of the basins involving and so it is not surprising that in Lake Qarun the main factors explaining primary productivity variability are water temperature, and soluble nitrate. Nevertheless, no statistical significant correlation has been found between primary productivity and other chemical variables. Schenler (1978) stated that phosphorus is generally the primary factor limiting phytoplankton growth and production in most lakes but it was not true in the present lake. 


\section{REFERENCES}

Abdel-Monem, A. M. (1991). Changes in the phytoplankton composition of Lake Qarun in relation to variation in salinity. M Sc. Thesis. Univ. Coll. for Girls. Ain Shams Iniv. $154 \mathrm{pp}$

Alvare\% (obelas,M; Haering.F.J; Velasco,J. L. and Rubio.A. (1992). The seasonal productivity of phytoplankton in hypertrophic. gravel-pit lake. J. Plankton Res., 14: 979-996

Anum ( $(x) 7)$. Iahe Q (arum Eeosystem Final report submitted to USAID $248 \mathrm{pp}$.

APHA (American Public Health Association ) (1992). "Standard methods for the examination of wastewater". $17^{\text {th }}$ edition. 1015 Fifteenth street. NW. Washington. DC 20005

Barica. J. (1981). Hydrotrophy-the ultimate stage of eutrophication. Water Quality Bull., 6: 95-98, 155-156

Booth. R.L. and Lobring, L.B. (1973). Evaluation of the auto-analyzer 11-A. Prg. Rep. in "advances in automated analysis"., 8: p.7.

Barnes. $\mathrm{H}$ and Folkard A. R. (1951). The determination of nitrite. Analyst, 96: 599.

Carpenter,S.R., Katchell, J.F.; Hodgson,J.R., Cochran,P.A.; Elser, J.J.; Elser,M.M.; Lodge,D.M.; Kretchmer,D. X. and von Ende, C.N. (1987). Regulation of lake primary productivity by food web structure. Ecology, 68: 1863-1876.

El-Sabrawy, G.M. and Taha O. E. (1999). Effect of grazing pressure of zooplankton on phytoplankton assemblang in Lake Qarun. El-Fayoum, Egypt. Egypt. J. Aquat. Biol\&Fish., 3: 81-92

Evans, C. A, Reilly J. E. O, and Thomas J. P. (1987). Biological investigations of marine antarctic systems and stocks (biomass). In. "A Handbook for Measurement of chlorophyll a and Primary Production". 8.Texas A \& M 
University, Collage Station. USA: 114 pp.

Gliwic\%. 7. M. (1977). Food size selection and seasonal succession of filterfeeding zooplankton in an eutrophic lake. Ekol. Pol., 25: $179-225$.

Grobbelaar, J.U, and Stegmann,P. (1976). Biological assessment of the euphotic zone in a turbid man-made lake, Hydrobiol., 48(3): 263-266.

Harris, G.P. (1978). Photosynthesis, productivity and growth; The physiological ecology of phytoplankton. Arch. Hydrobiol. Beth. Ergebn. Limnol. Helf, 10: 1-171 pp.

Harris,G.P.; Haffner,G.D. and Piccinin, B.B. (1980). Physical variability and phytoplankton communities, II: Primary productivity by phytoplankton in a physically variable environment. Arch. Hydrobiol., 88: 393-425.

Holm-Hansen. O.; Lorenzen C.J.; Holmes R.W.and Strickland J.D.H. (1965). Flurometric determination of chlorophyll. J. Cans. Perm. Int. explor. Mer., 30: 3-15.

Jassby, A.D, Goldman C.R.and Powell M. ( 1992). Trend, seasonality, cycle, and irregular fluctuations in primary productivity at Lake Tahoe, California-Nevada, USA. Hydrobiol., 246: 195-203.

Jewson, D.H. and Wood, R.B. (1975). Some effects on integral photosynthesis of artificial circulation of phytoplankton through light gradients. Verh Int. Verein. Limnol., 19, 10371044.

Kalff, I.K., and Watson S. (1986). Phytoplankton and its dynamics in two tropical lakes: a tropical and temperate zone comparison. Hydrobiol., 138: 161-176.

Lehman. J.T., and Sandgren, C.D. (1978). Documenting a seasonal change from phosphorus to nitrogen limitation in a small temperate lake and its impact on the population dynamics of Isterionella. Verh. Int. Ver. Iimnol.. 20: 375-380. 
Nydahi, f. (1976). On the optimum conditions for the reduction of nitrate by cadmium. Talanta, 23-249.

Parsons, T. R.; Maita Y. and Lalli C. M. (1984). "A manual of chemical and biological method for sea-water analysis". Pergamon Press, Oxford, $173 \mathrm{pp}$.

Peterson, B. T. (1980). Aquatic primary productivityand the ${ }^{14} \mathrm{C}-\mathrm{CO}_{2}$ method: A history of the productivity problem. Ann. Rev. Ecol. Syst., II: 359-385.

Robarts, R.D. (1981). Standardization of inorganic ${ }^{14} \mathrm{C}$ solutions. J. Limnol. Soc. South. Afr., 7: 76.

Robarts, R.D. (1984). Factors controlling primary production in a hypertrophic lake ( Hartbeesport Dam, South Africa). J. Plankton Res., 6: 91-105.

Schindler, D.W, (1977). The evolution of phosphorus limitation in lakes. Science (Wash., D.C.) 195: 260-262.

Schindler,D.W, (1978). Factor regulating phytoplankton production and standing crop in the world's freshwaters. Limnol. Oceanogr., 23: 470-487.

Schindler, D.W. and Free E.J. (1973). Durinal variation of dissolved organic carbon and its use in estimating primary productivity and $\mathrm{CO}_{2}$ invasion in Lake 227. J. Fish. Res. Board Can., 30: 1501-1510.

Sieburth, J.McN.; Smetacek, V. and Lenz, J. (1978). Pelagic ecosystem structure: heterotrophic compartments of the plankton and their relationship to plankton size fractions. Limnol. Oceanogr., 23: 1256-1263.

Strickland, J.D.H. and Parsons, T.R. (1972). A practical handbook of seawater analysis. Bull. Fish. Res. Board Can 167: 310 pp.

Taha, O.E and Abdel-Monem, A.M. (1999). Phytoplankton composition, biomass and productivity in Wadi El-Raiyan Lakes, Egypt. The 2nd Scientific Conference on The Role of 
Science in the Development of Egyptian Society and Environment. Fac. Science. Benha. Zagaziz Univ. (In press).

Talling, J.F. (1971). The underwater light climate as a controlling factor in the production ecology of freshwater phytoplankton. mitt. Int. Ver. Theor. angew. Limnol., 19: 214-243.

Tilzer, M .M. (1983). The importance of fractional light absorption by photosynthetic pigments for phytoplankton productivity in lake Constance, Limnol. Oceanogr., 28(5): 833-846.

Tilzer, M .M. (1989). The productivity of phytoplankton and its control by resource availability. In Kumar. H.D. (ed.), Phycotalk, 1. Banaras Hindi University, Varanasi (India): 22-40 pp.

Waston, S and McCauley. E. (1988). Contrasting pattern of net- and nanoplankton production and biomass among lakes. Can. J. Fish. Aquat. Sci., 45: 915-920

Yentsch, C.S. and Menzal D.W (1963). A method for the determination of phytoplankton chlorophyll and phaeophytin by fluorescence. Deep-Sea Res., 10: 221-231. 
Table (I). Regression between statistically correlated ecological parameters with primary productivity.

\begin{tabular}{|l|c|c|c|c|}
\hline Covariant & Coefficient & $R^{2}$ & $P$ & $F$ \\
\hline Total Chl a & 5.55 & 0.77 & 0.00017 & 33.66 \\
Nanoplankton & 7.66 & 0.81 & 0.00007 & 42.43 \\
Netplankion & 10.47 & 0.35 & 0.043 & 5.32 \\
Water temprature & 11.27 & 0.85 & 0.00002 & 58.83 \\
NO & 31.27 & 0.66 & 0.001 & 19.52 \\
IIN & 31.27 & 0.37 & 0.036 & 5.85 \\
\hline
\end{tabular}

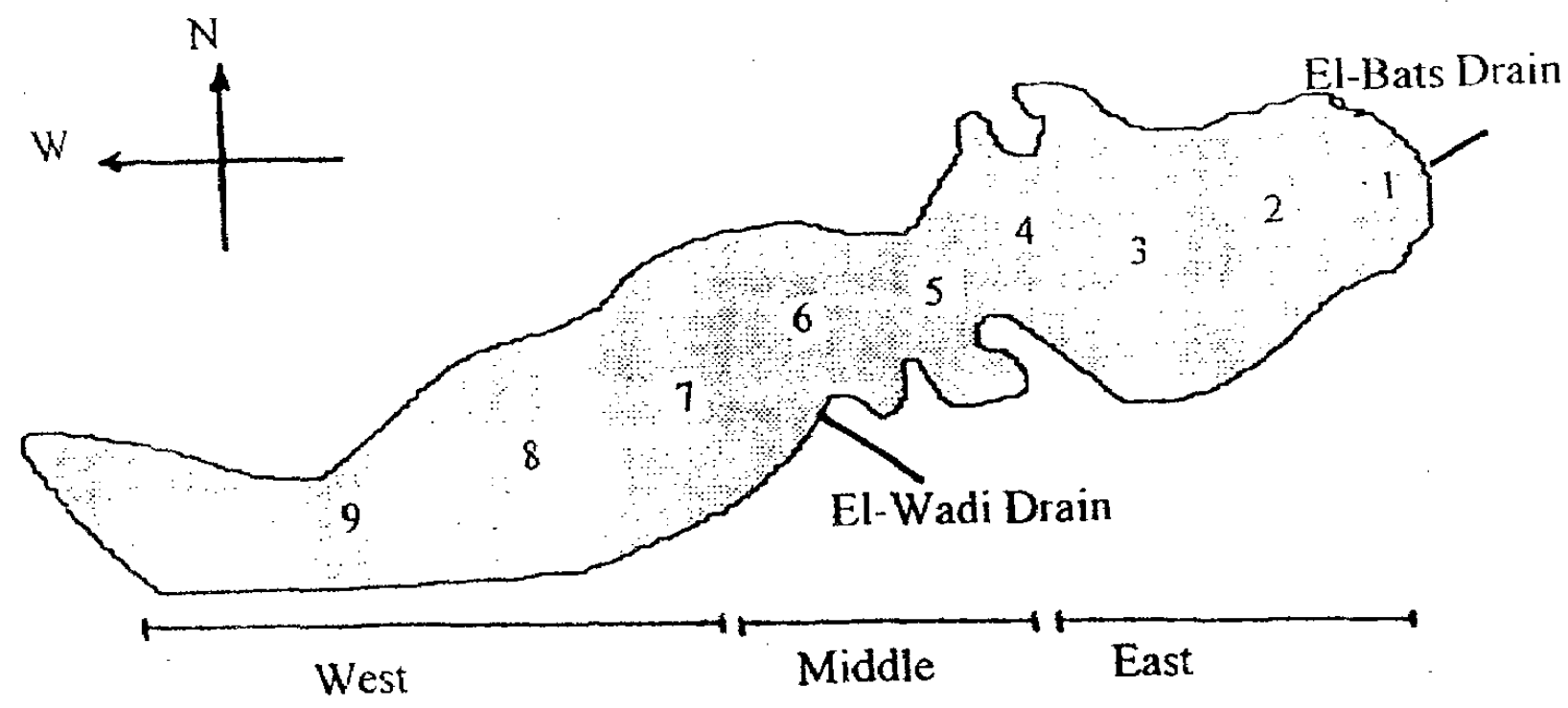

Fig (1): Sampling stations in Lake Qarun 
Jan. Fab Mar. Apr May Jun Jul Aug Sef Oel Nov Dec

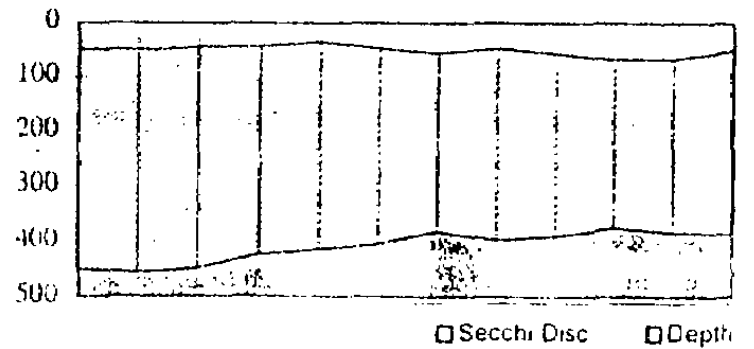

Fig (?): Monthly iverage of depth and Sechi-Depth

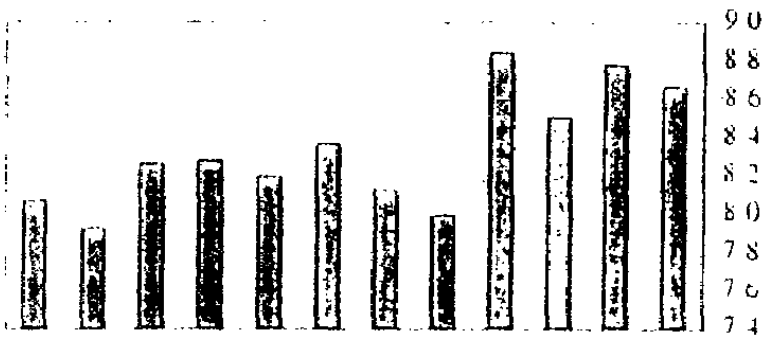

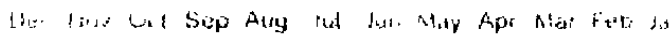

1.p2(1). Monthly averige of pll values:

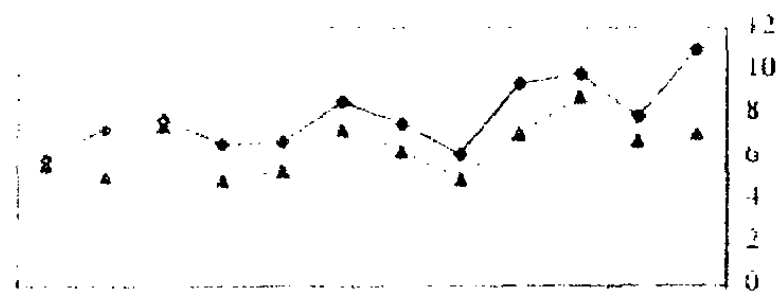

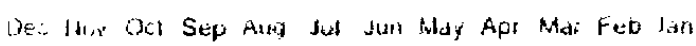

- Surtacie a Buticon

Fig (6) Monthly averiage of divolved oxygen

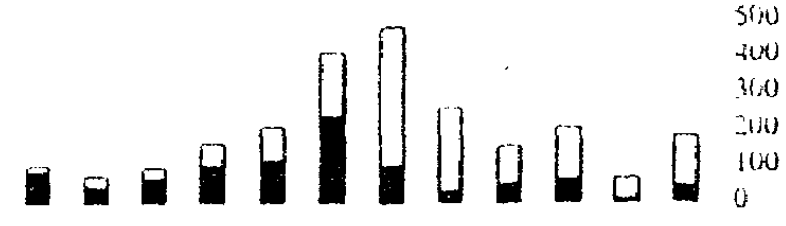

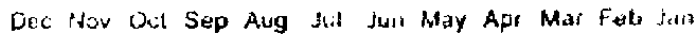

DHOS WNO3 DNHA:

Fig. (8): Monthly average of nitrogen netricots

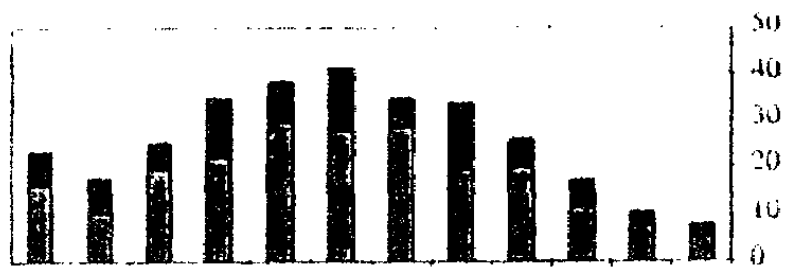

Dec Nov Oat Sep Aug Jut Jun May Apr Mat Feb Jan

Genono its:

Fig (10): Total Ch a (nato and net chi a)

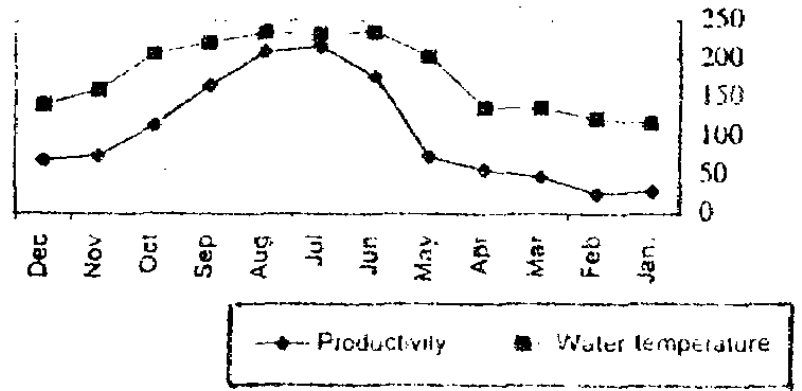

Fig (3): Primary productivity is water temperature.

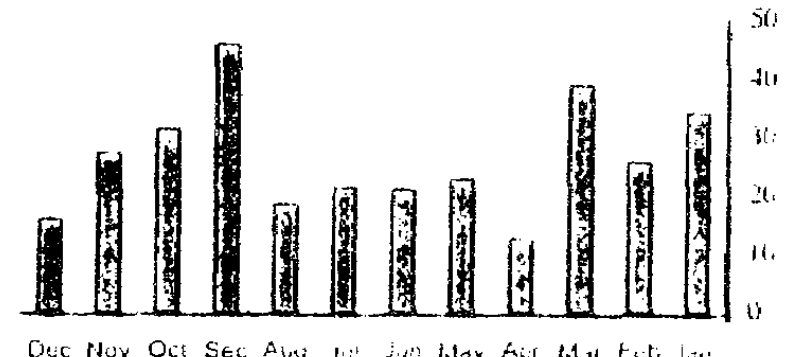

Hig.(5): Monthly averdge of wated tubidits

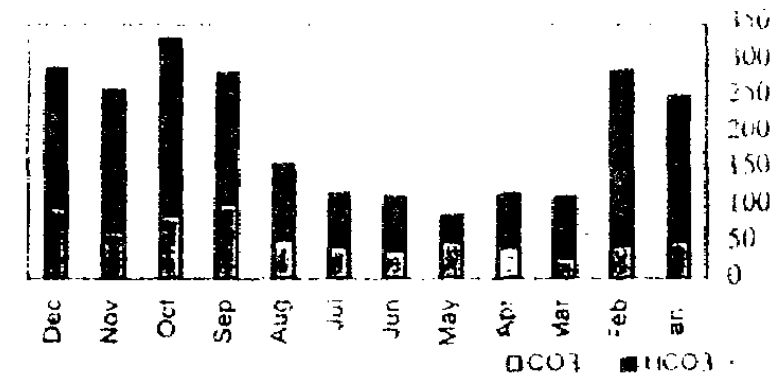

Fig (7): Water alkalinity (caitronate and bicalbon.tc)

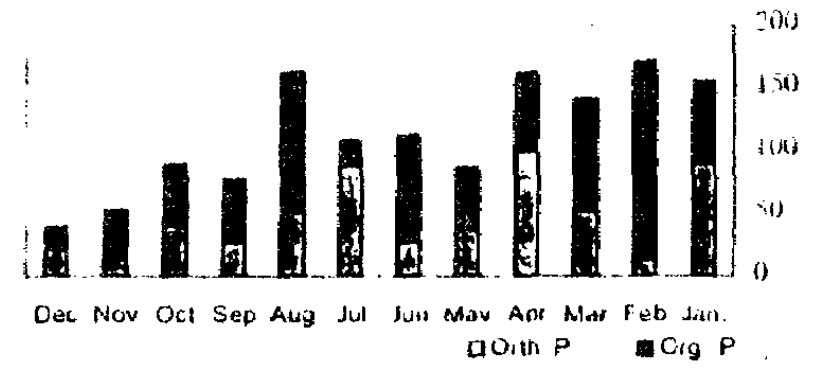

Fig (9): Phusphorus muticnts (ortho and organic). 